\title{
De kernpunten uit de uitgebreide controleverklaring in relatie tot de risico's in het bestuursverslag en de schattingen en oordelen in de toelichting
}

Arjan Brouwer, Peter Eimers en Henk Langendijk

SAMENVATTING Decennialang hebben accountants het oordeel bij de jaarrekening gecommuniceerd via standaardbewoordingen in de controleverklaringen. Stakeholders verwachten echter meer informatie van de accountant. Het beperkte inzicht in de werkzaamheden heeft mede bijgedragen aan de onvrede over het functioneren van accountants. De uitgebreide controleverklaring is een antwoord op deze informatiebehoefte van stakeholders. De kernpunten die worden gerapporteerd door de accountant geven de lezer van de jaarrekening nieuwe inzichten in het belang van de door de onderneming gerapporteerde kritische schattingen en risico's. Andersom mag van de accountant worden verwacht dat hij meer dan gemiddeld aandacht heeft geschonken aan de meest kritische schattingen en risico's bij de uitvoering van de controle. In dit artikel is onderzocht in welke mate de kernpunten in de uitgebreide controleverklaring overeenkomen met de genoemde risico's in het bestuursverslag alsmede de kritische grondslagen en schattingen in de toelichting. Wij hebben de bestuursverslagen, jaarrekeningen en controleverklaringen over boekjaar 2015 onderzocht van de 50 ondernemingen die deel uitmaken van de AEX- en Midkap-index. Uit ons onderzoek blijkt dat de in de uitgebreide controleverklaring genoemde kernpunten vaak overeenkomen met de kritische grondslagen en schattingen zoals verwoord door het bestuur van ondernemingen in de toelichting. In slechts $10 \%$ van de gevallen komt een risico zoals opgenomen in het bestuursverslag terug als kernpunt in de uitgebreide controleverklaring. De accountant heeft namelijk een sterke focus op balansposten als kernpunt. Zaken als betrouwbaarheid en continuïteit van IT en het voldoen aan wet- en regelgeving worden door veel ondernemingen gezien als risico maar komen nauwelijks terug in de kernpunten. Dat geldt in zijn algemeenheid voor aspecten van de interne beheersing van de gecontroleerde ondernemingen.
RELEVANTIE VOOR DE PRAKTIJK Het is voor bestuurders, commissarissen, professionele gebruikers en accountants van belang om kennis te nemen van de kernpunten die in de uitgebreide controleverklaring aan de orde komen. De in dit artikel onderzochte overeenkomsten en verschillen tussen deze kernpunten van de accountant en de genoemde risico's in het bestuursverslag alsmede de kritische grondslagen en schattingen in de toelichting bij de jaarrekening geven meer inzicht in de relevantie van de gerapporteerde schattingen en risico's voor de jaarrekening. Andersom geven de resultaten aanleiding voor accountants voor een evaluatie van de gerapporteerde kernpunten in het licht van door de ondernemingen gerapporteerde belangrijkste risico's.

\section{Inleiding}

De controleverklaring is voor veel gebruikers van de jaarrekening het enige dat zichtbaar is van het werk van de accountant. Jarenlang bevatte deze verklaring standaardbewoordingen en leverde deze geen andere informatie op dan de bevestiging van de accountant dat de jaarrekening een getrouw beeld gaf in overeenstemming met de van toepassing zijnde wet- en regelgeving. Stakeholders hadden en hebben echter behoefte aan meer inzicht in het werk van de accountant en zijn oordelen bij de jaarrekening en het bestuursverslag (zie onder andere VEB, 2013, VEB 2015 en Eume- 
dion 2013). Om aan deze wens van stakeholders tegemoet te komen hebben accountants de afgelopen jaren gewerkt aan het verbeteren van hun communicatie met stakeholders, onder andere via een actievere rol op de algemene vergadering en een pilot met een informatievere controleverklaring bij de jaarrekening over het boekjaar 2013 (zie ook NBA, 2013; Brouwer, Eimers, De Groot \& De Groot, 2014; NBA, 2015; Eumedion, 2015; PwC, 2015 en VEB, 2016).

Nadat over het boekjaar 2013 reeds een pilot had plaatsgevonden met het gebruik van de uitgebreide controleverklaring bij een aantal beursfondsen, heeft de Werkgroep Toekomst Accountantsberoep (2014) een maatregel in haar rapport opgenomen gericht op de afgifte van een uitgebreide controleverklaring bij alle OOB's. Niet lang daarna heeft de NBA Standaard $702 \mathrm{~N}$ uit de Nadere Voorschriften Controle- en Overige Standaarden (NV COS) definitief gemaakt en daarmee de uitgebreide controleverklaring verplicht gesteld bij de controle van alle OOB's in Nederland. Hiermee liep Nederland samen met het Verenigd Koninkrijk (VK) voorop in de wereld (Eimers \& De Groot, 2015). Op basis van EU-regelgeving (EU, 2014) en International Standard of Auditing 701 Communicating key audit matters in the independent auditor's report (IAASB, 2015) wordt toepassing van de uitgebreide controleverklaring verplicht voor de controle van beursfondsen vanaf boekjaren die starten op of na 17 juni 2016 (EU-regelgeving) respectievelijk boekjaren die eindigen op of na 15 december 2016 (ISA 701). De regelgeving in de Verenigde Staten (VS) is op dit vlak nog in ontwikkeling (PCAOB, 2015). De tijdelijke Nederlandse Standaard $702 \mathrm{~N}$ zal worden vervangen door de Standaard 701, aangevuld met een aantal specifiek Nederlandse bepalingen, onder andere rond de materialiteit en de reikwijdte van de groepscontrole.

Via de uitgebreide controleverklaring geeft de accountant meer inzicht in zijn controle, onder andere door het vermelden van de kernpunten van de controle, de materialiteit en de reikwijdte van een groepscontrole (Standaard 702N, par. 6b). De kernpunten van de controle zijn de aangelegenheden die in de professionele oordeelsvorming van de accountant het meest significant waren in de controle van de financiële overzichten van de huidige controleperiode (Standaard 702N, par. 7). Expliciet geeft Standaard 702N, par. 18a aan dat de door de accountant gerapporteerde kernpunten geen vervanging kunnen zijn voor toelichtingen in de financiële overzichten die door het van toepassing zijnde stelsel van financiële verslaggeving vereist zijn van het management of die anders noodzakelijk zijn voor het getrouwe beeld. In beginsel verschaft de accountant derhalve informatie over of naar aanleiding van zijn controle.
In de praktijk is het echter mogelijk dat de controleverklaring wel meer informatie geeft dan gebruikers hebben verkregen via de verantwoording door de onderneming. Abma van Eumedion zegt hierover in een interview (PwC, 2015) het volgende:

"We zien nogal eens een discrepantie tussen de controleverklaring en het verslag van de rvc. Dan staan er bijvoorbeeld belangrijke zaken in de verklaring die niet terugkomen in het verslag van de rvc. (......) Nu is het soms de omgekeerde wereld: het bestuur en de rvc geven soms zo weinig informatie over het risicoprofiel van de onderneming, dat bij dat soort ondernemingen de controleverklaring informatiever is dan het directieverslag en het verslag van de rvc. Dat is niet hoe het zou moeten zijn".

Ook in haar evaluatie van het Algemene vergadering van Aandeelhouders (AvA)-seizoen 2015 stelt Eumedion (2015) dat in sommige gevallen de inhoud van de controleverklaring meer informatie opleverde over de daadwerkelijke financiële situatie van een vennootschap dan het beeld dat geschetst werd in het bestuursen commissarissenverslag. De Bos en Strating (2014) stellen dat de uitgebreide controleverklaring ook invloed heeft op de rolverdeling tussen accountant, bestuur en commissarissen en de rapportage van bestuur en auditcommissies in het bestuursverslag.

Daarnaast maakt de accountant een keuze ten aanzien van die zaken die hij vermeldt in de controleverklaring. Daarmee kan de controleverklaring ervoor zorgen dat de aandacht van de gebruiker wordt gericht op de meest relevante zaken in de jaarrekening en het bestuursverslag. De afgelopen jaren hebben veel partijen de omvang van de jaarverslaggeving aan de orde gesteld en aangegeven dat dit de leesbaarheid van jaarrekening en bestuursverslag ondermijnt (zie bijvoorbeeld FRC, 2009; ASB \& FRC, 2011; Eumedion, 2012; Hoogervorst, 2012; Van Daelen, 2013 en Backhuijs \& Roelofsen, 2014). Het feit dat de accountant in de controleverklaring aangeeft welke zaken voor hem de belangrijkste aandachtspunten waren, en waarom dat het geval was, is naar onze mening in het licht hiervan een belangrijke functie van de controleverklaring.

Om die reden geeft de uitgebreide controleverklaring niet alleen informatie door de accountant over zijn controle, maar ook een waardevolle aanvulling op het geheel van informatie over de financiële verantwoording zoals die via de jaarverslaggeving wordt verstrekt aan de gebruikers. Vanuit die invalshoek onderzoeken wij de inhoud van de uitgebreide controleverklaring bij Nederlandse beursgenoteerde ondernemingen en brengen dit in relatie tot de door de ondernemingen verstrekte informatie in het bestuursverslag en de jaarrekening. Specifiek richten wij ons hierbij op de risicoparagraaf in het bestuursverslag en de kritische grondslagen en schattingen in de jaarrekening. De 
belangrijke risico's zoals door het bestuur van een onderneming verwoord in het bestuursverslag en de kritische grondslagen en schattingen van de leiding van een onderneming bij het opstellen van de jaarrekening kunnen uitmonden in corresponderende kernpunten van de controle van de controlerende accountant.

De doelstelling van dit artikel is om te onderzoeken of en in welke mate er overeenstemming is tussen het type kernpunt in de uitgebreide controleverklaring, de genoemde belangrijke risico's in het bestuursverslag en in de toelichting vermelde kritische grondslagen en schattingen bij het opstellen van de jaarrekening. Allereerst beschrijft paragraaf 2 de regelgeving en literatuur. Paragraaf 3 bevat de resultaten van ons empirisch onderzoek. Dit artikel wordt afgesloten met een samenvatting en conclusies in paragraaf 4 .

\section{Regelgeving en literatuur over uitgebreide con- troleverklaring, belangrijke risico's en belang- rijke schattingen en oordelen}

\subsection{De uitgebreide controleverklaring}

Decennialang hebben accountants het oordeel bij de jaarrekening gecommuniceerd via standaardbewoordingen in de controleverklaringen. Stakeholders verwachten echter meer informatie van de accountant zoals blijkt uit onder andere uitingen van de VEB (2013 en 2015) en Eumedion (2013). Het beperkte inzicht in de werkzaamheden heeft mede bijgedragen aan de onvrede over het functioneren van accountants. De Werkgroep toekomst accountantsberoep (2014) stelt dat de maatschappij jarenlang te weinig heeft gezien van wat accountants doen en dat niet kan worden verwacht dat de maatschappij haar vertrouwen slechts baseert op de standaardcontroleverklaring. Litjens en Vergoossen (2012) concluderen dat er sprake is van samenhang tussen de verwachtingskloof en de communicatie van de accountant. Zij stellen dat grote winst geboekt kan worden door meer informatie op te nemen in de controleverklaring over controlewerkzaamheden en controlebevindingen. Ook geven zij aan dat de informatie meer specifiek betrekking dient te hebben op de gecontroleerde onderneming. Ook Wieringa (2015) benadrukt het belang van betere communicatie door accountants via onder andere de controleverklaring en op aandeelhoudersvergaderingen. De Bos en Strating (2014) stellen dat de aanleiding voor de uitgebreide controleverklaring is gelegen in de verwachtings- en informatiekloof en zijn van mening dat de uitgebreide controleverklaring een belangrijke stap is om te voldoen aan de verwachtingen in het maatschappelijk verkeer.

De internationale literatuur over de effecten van deze nieuwe ontwikkelingen is beperkt. In de aanloop van de vaststelling van de IAASB-standaard en de discus- sies in de VS heeft een aantal onderzoekers getracht de mogelijke effecten in beeld te brengen. Zo verkennen Gold, Gronewold en Pott (2012) de mogelijke effecten van een uitgebreidere controleverklaring op de verwachtingskloof. Czerney, Schmidt en Thompson (2014) onderzoeken of toevoegingen in de controleverklaring een verhoogd risico op materiële fouten zou suggereren. Christensen, Glover, Steven en Wolfe (2014) onderzoeken het effect van kernpunten in de controleverklaring op het gedrag van investeerders. Van eerdere datum zijn de publicaties van onder andere Turner, Mock, Coram en Gray (2010) en Gray, Turner, Coram en Mock (2011), die het onbehagen over de oude 'one-size-fits all' controleverklaring onderzoeken.

Met het verschijnen van de eerste informatievere controleverklaringen verschijnen ook de rapporten, waaronder de jaarlijkse FRC-publicatie (zie onder andere FRC, 2016) en de jaarlijkse award voor de meest informatieve controleverklaring in het VK, Ook in Nederland verschijnen benchmarkrapporten (Brouwer, Eimers, De Groot \& De Groot, 2014; NBA, 2015).

\subsection{Informatieverschaffing over belangrijke risico's}

Op grond van art. 2:391 lid 1 BW geeft het bestuursverslag een beschrijving van de voornaamste risico's en onzekerheden waarmee de rechtspersoon wordt geconfronteerd. RJ 400.110a geeft aan dat het hierbij niet gaat om het opnemen van een uitputtende uiteenzetting van alle mogelijke risico's en onzekerheden, maar om een selectie en weergave van de belangrijkste risico's en onzekerheden waarvoor de rechtspersoon zich ziet geplaatst. Deze regelgeving is ook van toepassing op jaarrekeningen in Nederland die op basis van IFRS worden opgesteld. Op grond van RJ 400.110b wordt verwacht dat een onderneming in ieder geval ingaat op de risico's op het gebied van de strategie, operationele activiteiten, financiële positie, financiële verslaggeving en wet- en regelgeving. Voor beursgenoteerde ondernemingen vereist ook de Code Corporate Governance (Monitoring Commissie Corporate Governance Code, 2008) dat in het bestuursverslag een beschrijving wordt gegeven van de voornaamste risico's gerelateerd aan de strategie van de vennootschap.

Van Daelen en De Groot (2014) stellen dat deze verplichtingen in wet- en regelgeving en codes niet op zichzelf staan, maar antwoord zijn op kritiek en vragen van stakeholders naar informatieverschaffing over risico's en risicomanagement. Ook in haar voorstellen voor herziening van de Corporate Governance Code (Monitoring Commissie Corporate Governance Code, 2016) stelt de Monitoring Commissie Corporate Governance Code diverse bepalingen voor ter versteviging van het risicomanagement. 
De Ridder en Steggink (2009) concluderen dat stakeholders behoefte hebben aan een specifieke uiteenzetting van de voor de onderneming belangrijke risico's en niet aan een opsomming van algemene risico's waarbij minimaal een rangorde en bij voorkeur een kwantificering van kans en impact wordt aangegeven. Onderzoek van Mertens \& Blij (2008) en Van Daelen en De Groot (2014) laat echter zien dat ondernemingen hier onvoldoende aan tegemoet komen en over het algemeen een groot aantal risico's rapporteren zonder goed inzicht te geven in het belang van deze risico's. Van Daelen en De Groot (2014) stellen vast dat de meerderheid van de ondernemingen 12 of meer risico's rapporteert en noemen dat een vrij ruime interpretatie van het begrip 'voornaamste'. Eumedion (2012) stelt dan ook: "A second suggestion in this regard is not to publish an extensive list of possible risks for the company, but to confine it to the most important ('top') risks". Van Daelen (2013) geeft een overzicht van internationale informatiebehoeften en internationaal onderzoek naar informatieverschaffing en hieruit blijkt eenzelfde beeld.

Risicoanalyse is een belangrijk startpunt van de controle en de accountant dient een controleprogramma te ontwikkelen dat adequaat inspeelt op deze risico's op materiële fouten in de jaarrekening (zie onder andere Standaarden 300, 315 en 330). De belangrijkste risico's zijn derhalve in sterke mate richtinggevend voor de controle. De door de rechtspersoon geïdentificeerde risico's zullen zich weliswaar niet in alle gevallen vertalen in risico's voor de controle van de jaarrekening over het boekjaar, maar wel mag verwacht worden dat zij een belangrijke bron vormen voor de risico-inschatting van de accountant. De confrontatie van de door de onderneming gerapporteerde risico's en de door de accountant in de kernpunten benoemde risico's die met name aandacht hebben gevraagd tijdens de controle levert de gebruiker derhalve relevante informatie op waarmee hij zich een beter beeld kan vormen over de belangrijkste risico's.

\subsection{Informatieverschaffing over belangrijke schattingen en oor- delen}

Het opstellen van een jaarrekening op basis van bijvoorbeeld IFRS vereist oordeelsvorming en het maken van schattingen. Het belang hiervan is in de tijd toegenomen. IAASB voorzitter Schilder (PwC, 2016) zegt hierover bijvoorbeeld: "Nu spelen harde cijfers een kleinere, en woorden en inschattingen een grotere rol. Er is veel meer toelichting nodig bij de totstandkoming van waarderingen, denk bijvoorbeeld aan de expected credit losses bij banken. Daar komen veronderstellingen en aannames bij kijken. Deze posten maken een veel groter deel van de balans uit dan vroeger."

Ondanks dat verschillende uitkomsten mogelijk zijn en dit afhankelijk is van de gehanteerde veronderstel- lingen is het in de huidige verslaggeving noodzakelijk dat dit wordt vertaald tot één bedrag dat wordt opgenomen op de balans of in de winst-en-verliesrekening. Dat bedrag geeft als zodanig echter geen informatie over de schattingsonzekerheden en mogelijke andere uitkomsten voor deze post (zie ook Backhuijs \& Roelofsen, 2014). Camfferman en Eeftink (2006) geven aan dat deze onzekerheid een additioneel attribuut is van het in de jaarrekening opgenomen bedrag. Vanwege het belang van schattingen en veronderstellingen noemen Backhuijs en Roelofsen (2014) de paragraaf over de kritische grondslagen en schattingsonzekerheden "wellicht het belangrijkste onderdeel van de IFRS-jaarrekening na de vier primaire overzichten”.

De informatieverschaffing over kritische grondslagen en schattingsonzekerheden is geregeld in IAS 1 (Presentatie van de jaarrekening). IAS 1.116 schrijft voor dat een entiteit in de toelichting informatie verschaft over de belangrijkste veronderstellingen betreffende de toekomst en andere belangrijke bronnen van schattingsonzekerheden op de balansdatum die een aanmerkelijk risico in zich dragen van een materiële aanpassing van de boekwaarde van de activa en verplichtingen in het volgende boekjaar. IAS 1.118 geeft een nadere duiding van het soort schattingen waar dan aan wordt gedacht. Het betreft volgens IAS 1.118 de schattingen waarbij de oordeelsvorming door het management het moeilijkst of het meest subjectief of complex is. Op grond van IAS 1.120 moet worden gedacht aan toelichting van de volgende informatie over deze schattingen:

(a) de aard van de veronderstelling of andere schattingsonzekerheden;

(b) de gevoeligheid van de boekwaarden voor de methoden, veronderstellingen en schattingen die aan hun berekening ten grondslag liggen, met inbegrip van de redenen van die gevoeligheid;

(c) de verwachte afloop van een onzekerheid en de bandbreedte van redelijkerwijs mogelijke uitkomsten in het volgende boekjaar ten aanzien van de boekwaarden van de desbetreffende activa en verplichtingen; en

(d) een verklaring van de aangebrachte wijzigingen in veronderstellingen die in het verleden zijn gemaakt met betrekking tot die activa en verplichtingen, indien de onzekerheid blijft bestaan.

IAS 1.113 geeft voorts aan dat een entiteit in het overzicht van belangrijke gehanteerde grondslagen voor financiële verslaggeving of elders in de toelichting naast de informatie inzake schattingen ook de oordelen moet vermelden die het management zich heeft gevormd bij de toepassing van de door de entiteit gehanteerde grondslagen voor financiële verslaggeving die het meest significante effect hebben op de in de jaarrekening opgenomen bedragen. 
Vergelijkbaar met de informatie over risico's laat eerder onderzoek (zie voor een overzicht Backhuijs en Roelofsen, 2014) zien dat ondernemingen een groot aantal kritische grondslagen en schattingsonzekerheden rapporteren wat het voor de gebruiker lastig maakt om inzicht te krijgen in dat wat echt belangrijk is.

Oordeelvorming en de controle van schattingen neemt een belangrijke plaats in binnen de controle. Als je alle standaarden bij elkaar pakt, dan zie je dat zeker de belft aan professionele oordeelsvorming raakt, aldus Schilder ( $\mathrm{PwC}$, 2016). Standaard 540 gaat bijvoorbeeld specifiek in op de controle van schattingen en Standaard 260 (par. 16 en bijlage 2) benoemt de grondslagen voor financiële verslaggeving en schattingen expliciet als onderwerpen waarover de accountant over het algemeen zal communiceren naar de met governance belaste personen. Verwacht mag dan ook worden dat in veel gevallen de meest kritische grondslagen en schattingen een plaats vinden in de kernpunten van de controle. Ook hier levert een confrontatie van de door de onderneming gerapporteerde kritische grondslagen en schattingen met de door de accountant gerapporteerde kernpunten relevante informatie op voor de gebruiker van de jaarrekening.

\section{Figuur 1 Best practice Toegankelijke presentatie in uitgebreide con- troleverklaring: Royal DSM Integrated Annual Report 2015, p. 199 (KPMG)}

\section{Audit approach}

Summary

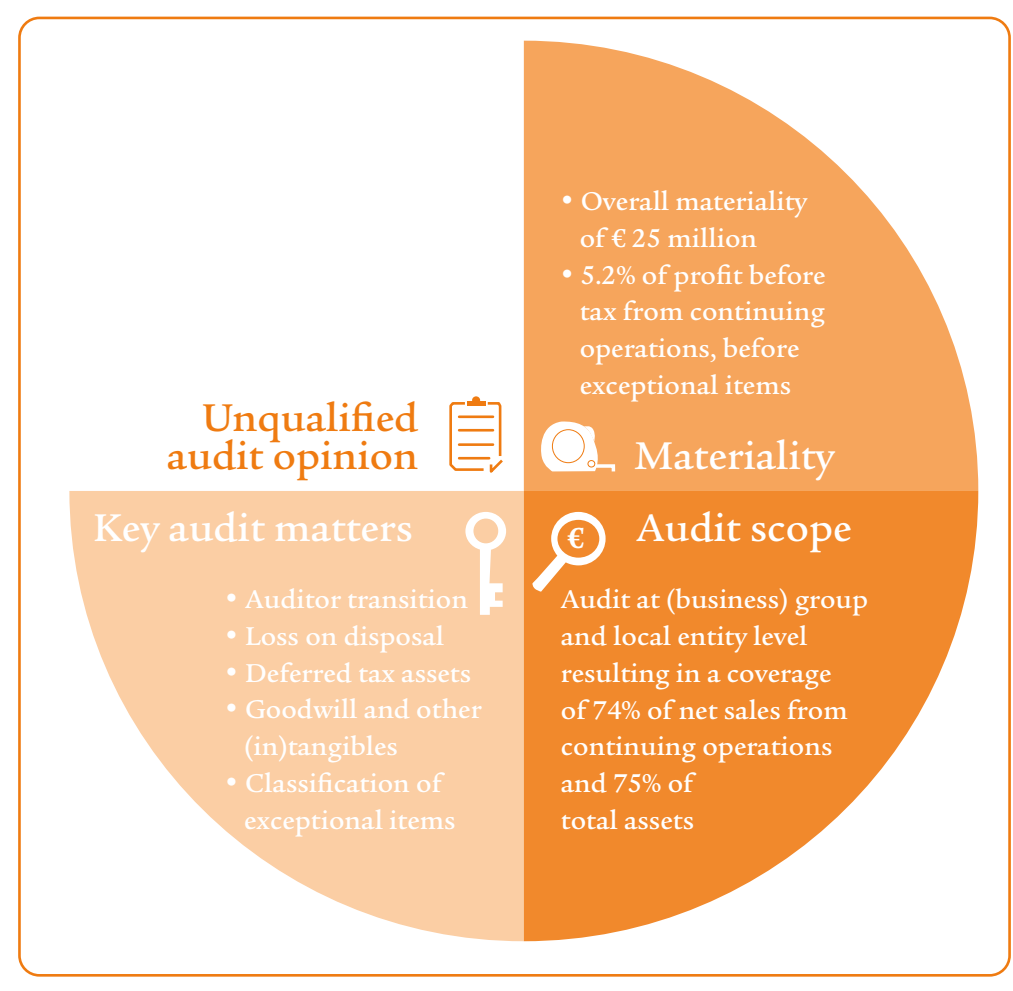

\section{Resultaten van empirisch onderzoek}

\subsection{Populatie}

Wij hebben de bestuursverslagen, jaarrekeningen en controleverklaringen over boekjaar 2015 onderzocht van de 50 ondernemingen die deel uitmaken van de AEX- en Midkap-index. Bij twee ondernemingen die deel uitmaken van de AEX-index (Arcelor Mittal en Unibail-Rodamco) en vier ondernemingen uit de Midkap-index (Air France - KLM, Aperam, Galapagos en WDP) heeft de accountant geen uitgebreide controleverklaring afgegeven. Het betreft hier ondernemingen met een buitenlandse rechtsvorm die formeel geen Organisatie van Openbaar Belang (OOB) in Nederland zijn en waarvoor een uitgebreide controleverklaring om die reden niet verplicht is. Voor deze ondernemingen zal de uitgebreide controleverklaring van toepassing worden zodra de EU-regelgeving van kracht is. Het is opvallend dat de positieve reacties van stakeholders in de Nederlandse omgeving op de bij andere ondernemingen over het boekjaar 2014 reeds afgegeven uitgebreide controleverklaringen voor deze ondernemingen geen aanleiding is geweest om hun accountant te verzoeken om in 2015 ook reeds bij hen deze stap te maken. Als gevolg hiervan worden in dit artikel de resultaten weergegeven van onderzoek naar de uitgebreide controleverklaringen van de 44 AEX- en Midkapfondsen waarbij deze wel is opgenomen.

\subsection{De controleverklaring}

De uitgebreide controleverklaring bevat informatie over onder andere de gehanteerde materialiteit, reikwijdte van de groepscontrole en de kernpunten van de controle. Als gevolg van deze extra informatie is de lengte van de controleverklaring aanzienlijk toegenomen en beslaat deze nu meerdere pagina's waar dat in het verleden over het algemeen beperkt bleef tot één pagina. Om deze informatie op toegankelijke wijze te ontsluiten hebben verschillende accountants ervoor gekozen om de belangrijkste informatie in één oogopslag inzichtelijk te maken. Een voorbeeld hiervan is opgenomen als best practice in figuur 1 .

Ons onderzoek richt zich op de informatie die in de controleverklaring wordt verstrekt over de kernpunten van de controle. Kernpunten zijn volgens Standaard $702 \mathrm{~N}$ aangelegenheden die in de professionele oordeelsvorming van de accountant het meest significant waren in de controle. Ze worden geselecteerd uit de aangelegenheden die zijn gecommuniceerd met de personen belast met governance. In de onderzochte controleverklaringen zijn door de accountant twee tot zes kernpunten opgenomen. Bij de AEX-fondsen zijn gemiddeld 4,43 kernpunten opgenomen in de controleverklaring en bij de Midkap-fondsen 3,95 kernpunten (zie ook tabel 1). 
Tabel 1 Aantal gerapporteerde kernpunten

\begin{tabular}{|l|r|r|r|r|r|r|}
\hline Aantal kernpunten & \multicolumn{2}{|c|}{ AEX } & \multicolumn{3}{|c|}{ Midkap } & \multicolumn{2}{|c|}{ Totaal } \\
\hline & $\mathrm{n}$ & $\%$ & $\mathrm{n}$ & $\%$ & $\mathrm{n}$ & $\%$ \\
\hline 1 & 0 & 0 & 0 & 0 & 0 & 0 \\
\hline 2 & 1 & 4 & 2 & 10 & 3 & 7 \\
\hline 3 & 6 & 26 & 7 & 33 & 13 & 30 \\
\hline 4 & 3 & 13 & 5 & 24 & 8 & 18 \\
\hline 5 & 8 & 35 & 4 & 19 & 12 & 27 \\
\hline 6 & 5 & 22 & 3 & 14 & 8 & 18 \\
\hline & & & & & & \\
\hline Totaal aantal fondsen & 23 & 100 & 21 & 100 & 44 & 100 \\
\hline $\begin{array}{l}\text { Totaal aantal } \\
\text { kernpunten }\end{array}$ & 102 & & 83 & & 185 & \\
\hline Gemiddeld aantal kernpunten & 4,43 & & 3,95 & & 4,20 & \\
\hline
\end{tabular}

In tabel 2 wordt weergegeven wat de aard is van de gerapporteerde kernpunten. Uit deze tabel blijkt dat het overgrote deel van de kernpunten betrekking heeft op specifieke balansposten. Bij de AEX-fondsen heeft $66 \%$ van de kernpunten betrekking op de balans en bij de Midkap-fondsen heeft 57\% van de kernpunten betrekking op de balans. Met name de controle van de belastingpositie (27 ondernemingen, $61 \%$ van de populatie) en van de goodwillwaardering ( 25 ondernemingen, $57 \%$ van de populatie) worden frequent door de accountant gerapporteerd als kernpunt. In totaal heeft $87 \%$ van de kernpunten betrekking op specifieke posten of toelichtingen in de jaarrekening. De meest ge-

\section{Tabel 2 Aard van de kernpunten}

\begin{tabular}{|c|c|c|c|c|c|c|}
\hline \multirow[t]{2}{*}{ Onderwerp } & \multicolumn{2}{|c|}{ AEX } & \multicolumn{2}{|c|}{ Midkap } & \multicolumn{2}{|c|}{ Totaal } \\
\hline & $\mathrm{n}$ & $\%$ & $\mathrm{n}$ & $\%$ & $\mathrm{n}$ & $\%$ \\
\hline \multirow{2}{*}{\multicolumn{7}{|c|}{ Jaarrekening - balansposten }} \\
\hline & & & & & & \\
\hline Belastingpositie & 16 & $16 \%$ & 11 & $13 \%$ & 27 & $15 \%$ \\
\hline Goodwillwaardering (incl. impairment) & 13 & $13 \%$ & 12 & $14 \%$ & 25 & $14 \%$ \\
\hline Overige immateriële- en materiële activawaardering & 7 & $7 \%$ & 10 & $12 \%$ & 17 & $9 \%$ \\
\hline Voorzieningen voor claims en geschillen & 7 & $7 \%$ & 4 & $5 \%$ & 11 & $6 \%$ \\
\hline Reorganisatievoorziening & 6 & $6 \%$ & 1 & $1 \%$ & 7 & $4 \%$ \\
\hline Pensioenvoorzieningen & 3 & $3 \%$ & 1 & $1 \%$ & 4 & $2 \%$ \\
\hline Overige voorzieningen & 4 & $4 \%$ & 1 & $1 \%$ & 5 & $3 \%$ \\
\hline Complexe financiële instrumenten & 3 & $3 \%$ & 3 & $4 \%$ & 6 & $3 \%$ \\
\hline Deelnemingen en joint ventures & 3 & $3 \%$ & 1 & $1 \%$ & 4 & $2 \%$ \\
\hline Overige balansposten & 5 & $5 \%$ & 3 & $4 \%$ & 8 & $4 \%$ \\
\hline Totaal balansposten & 67 & $66 \%$ & 47 & $57 \%$ & 114 & $62 \%$ \\
\hline \multicolumn{7}{|l|}{ Jaarrekening - winst-en-verliesrekening } \\
\hline Omzetverantwoording & 9 & $9 \%$ & 11 & $13 \%$ & 20 & $11 \%$ \\
\hline Totaal winst-en-verliesrekening & 9 & $9 \%$ & 11 & $13 \%$ & 20 & $11 \%$ \\
\hline \multicolumn{7}{|l|}{ Jaarrekening - overig } \\
\hline Acquisities & 5 & $5 \%$ & 5 & $6 \%$ & 10 & $5 \%$ \\
\hline Verkoop activiteiten & 3 & $3 \%$ & 3 & $4 \%$ & 6 & $3 \%$ \\
\hline Effecten beursgang/overname (delisting) & 1 & $1 \%$ & 2 & $2 \%$ & 3 & $2 \%$ \\
\hline Financiering / going concern & - & - & 3 & $4 \%$ & 3 & $2 \%$ \\
\hline Overig & 3 & $3 \%$ & 1 & $1 \%$ & 4 & $2 \%$ \\
\hline Totaal jaarrekening - overig & 12 & $12 \%$ & 14 & $17 \%$ & 26 & $14 \%$ \\
\hline \multicolumn{7}{|l|}{ Interne beheersing } \\
\hline Betrouwbaarheid en continuïteit IT & 3 & $3 \%$ & 3 & $4 \%$ & 6 & $3 \%$ \\
\hline Overig interne beheersing & 3 & $3 \%$ & 4 & $5 \%$ & 7 & $4 \%$ \\
\hline Totaal interne beheersing & 6 & $6 \%$ & 7 & $8 \%$ & 13 & $7 \%$ \\
\hline \multicolumn{7}{|l|}{ Overige onderwerpen } \\
\hline Eerstejaarscontrole & 6 & $6 \%$ & 3 & $4 \%$ & 9 & $5 \%$ \\
\hline Overig & 2 & $2 \%$ & 1 & $1 \%$ & 3 & $2 \%$ \\
\hline Totaal overige onderwerpen & 8 & $8 \%$ & 4 & $5 \%$ & 12 & $6 \%$ \\
\hline Totaal & 102 & $100 \%$ & 83 & $100 \%$ & 185 & $100 \%$ \\
\hline
\end{tabular}


noemde kernpunten zijn Belastingpositie (15\%), Goodwillwaardering (inclusief impairment) (14\%) en Omzetverantwoording (11\%). Dit is in lijn met de empirische resultaten van de FRC (2016) voor het VK. Slechts $14 \%$ van de kernpunten heeft betrekking op aspecten van interne beheersing (7\%), de eerstejaarscontrole (5\%) of andere aspecten (2\%). Dit komt overeen met de empirische resultaten in een studie van de FRC (2016, pp. 14-16) met betrekking tot de FTSE 350 in het VK waar ook de gerapporteerde kernpunten primair betrekking hebben op jaarrekeningposten.

De mate waarin kernpunten specifiek zijn gemaakt voor de situatie van de gecontroleerde onderneming verschilt van geval tot geval. Meerdere accountants beschrijven bijvoorbeeld in generieke zin de reden waarom goodwillwaardering een kernpunt is (omvangrijk bedrag en vereist schattingen) zonder in te gaan op specifieke componenten van het totale goodwillbedrag waar de controle-inspanning met name op heeft toegezien of beschrijven in generieke zin dat een eerstejaarscontrole specifieke aandacht vraagt van de accountant. In figuur 2 is een best practice opgenomen van een kernpunt waarin de accountant specifiek aangeeft in welk land of segment de onzekerheid zich manifesteert.

Eén van de overige onderwerpen betreft een kernpunt dat door EY is opgenomen in de controleverklaring bij de jaarrekening van KPN. Zie hiervoor best practice in figuur 3. EY beperkt zich hier niet tot kernpunten over de controle van de jaarrekening, maar heeft ook een kernpunt opgenomen met betrekking tot haar assurance-werkzaamheden bij de sustainability-informatie in het bestuursverslag. Dit sluit goed aan bij de vraag vanuit stakeholders om als accountant ook nadrukkelijker een oordeel te geven over het bestuursverslag en andere informatie die relevant is voor de oordeelsvorming over de onderneming. Hierbij zij opgemerkt dat de accountant zich beperkt tot het weergeven van zijn werkzaamheden en niet ingaat op de eventuele gevoeligheden van de genoemde veronderstellingen.

\section{Figuur 2 Best practice Accountant specificeert onzekerheid ten aanzien van kernpunt: SBM Offshore Annual report 2015, p. 216 (PwC)}

\section{Key audit matter}

Difficult market conditions, no new projects from Brazil (their main market), and the Company's restructuring actions

The drop in the oil price and the need for the Company's clients to reassess and reduce their capex plans and embark on other cost savings initiatives, together with the situation in Brazil whereby the company was excluded from participating in tenders, has caused the Company to reassess its business model. They have initiated a number of alignment and restructuring initiatives aimed at reducing the Company's work force. The continued deterioration of market conditions could have an impact on the Company's financial position and results - particularly its Turnkey segment - and we therefore focused significantly on matters such as judgements, valuations, provisioning and future scenarios, all of these are disclosed in more detail below as it regards to key audit matters.

\section{How our audit addressed the matter}

We have had discussions with management to understand their plans and business changes. We have considered management's assessment whether the Company would face liquidity problems as a result from the downturn in the industry, and the circumstances the Company is facing in Brazil as described in note 6.3.1 of the financial statements. Our audit procedures included obtaining a liquidity forecast and assessment of the effects of the different liquidity scenarios on the Company's compliance with its bank loan covenants. We have compared the business plans and assumptions with market data as well as with the lease contracts commenced that generate cash flows in the upcoming years. We have compared this to management's estimates included in the liquidity scenarios and concur with management's conclusion that there are no material uncertainties with respect to going concern. We have assessed the appropriateness and timing of expenses incurred for restructuring.

\section{Figuur 3 Best practice Accountant bespreekt zijn werkzaamheden betreffende assurance van sustainability-informatiie: KPN Integrated Annual Report 2015, p. 169 (EY)}

\begin{tabular}{|c|c|}
\hline Key assurance matter & How our assurance procedures addressed the matter \\
\hline \multicolumn{2}{|l|}{ Estimations in Scope 3 emissions and energy reduction by customers } \\
\hline $\begin{array}{l}\text { Inherent to the nature of scope } 3 \text { emissions, KPN uses estimates and underlying } \\
\text { assumptions to determine the indirect emissions in its value chain. } \\
\text { As of 2014, KPN started reporting on the estimated reduced energy consumption } \\
\text { by KPN's customers through the use of its products and services. KPN implemen- } \\
\text { ted a model to estimate the positive impact of its products and services, while } \\
\text { taking potential negative impacts into account. }\end{array}$ & $\begin{array}{l}\text { Our review procedures focused on understanding the model used and assessing } \\
\text { the mathematical accuracy of the calculations applied and validated the assump- } \\
\text { tions with underlying sources. }\end{array}$ \\
\hline
\end{tabular}




\subsection{De controleverklaring in relatie tot de risicoparagraaf en de kritische grondslagen en schattingen}

Zoals in paragraaf 2 aangegeven kan de controleverklaring een nuttige functie vervullen door vanuit het perspectief van de accountant inzicht te geven in de voor de controle meest kritische risico's en schattingen. In tabel 3 wordt inzicht gegeven in het aantal gerapporteerde kernpunten ten opzichte van de door de onderneming gerapporteerde risico's en kritische grondslagen/schattingen.

Uit tabel 3 blijkt dat het gemiddeld, minimum en mediaan aantal kernpunten in de uitgebreide controleverklaring en het gemiddeld, minimum en mediaan aantal kritische grondslagen en schattingen in de toelichting redelijk hetzelfde beeld geven. Wel liggen het maximum, gemiddelde en de mediaan van het aantal kernpunten lager dan het aantal kritische grondslagen en schattingen. Het gemiddeld, mediaan en maximum aantal risico's is veel groter dan het aantal kernpunten en kritische grondslagen en schattingen. Dit sluit aan bij de in paragraaf 2.2. besproken literatuur waarin melding wordt gemaakt van het feit dat over het algemeen veel risico's worden gerapporteerd en veel ondernemingen zich niet beperken tot het rapporteren van alleen de voornaamste risico's. Een uitzondering hierop is Delta Lloyd (figuur 4) die expliciet de vijf belangrijkste risico's afzonderlijk rapporteert.

Wij benaderen dit vanuit drie invalshoeken. In tabel 4 wordt weergegeven wat de aard is van de gerapporteerde kernpunten en in welke mate tegenover de door de accountant gerapporteerde kernpunten ook door de onderneming een kritische grondslag/schatting of ri- sico is gerapporteerd. In tabel 5 wordt de relatie tussen door de onderneming gerapporteerde kritische grondslagen en schattingen en de door de accountant gerapporteerde kernpunten weergegeven uitgaande van de gerapporteerde kritische grondslagen. In tabel 6 wordt weergegeven welke risico's door de onderneming worden gerapporteerd en welke hiervan terugkomen in de kernpunten van de controle.

Uit tabel 4 blijkt dat veel kernpunten betrekking hebben op een aspect dat ook door de onderneming is aangemerkt als kritische grondslag of schatting. Bij $62 \%$ van de kernpunten is dit het geval. Dit sluit aan bij het gegeven dat een groot deel van de kernpunten betrekking heeft op balansposten aangezien ook de kritische grondslagen en schattingen voornamelijk zijn gericht op de verwerking en waardering van balansposten (zie ook tabel 5). Voor een minder groot deel van de kernpunten (38\%) komt een gerelateerd risico terug in de risicoparagraaf. Hierbij wordt wel opgemerkt dat waardering van goodwill en andere activa bij veel ondernemingen niet specifiek wordt genoemd in de risicoparagraaf, maar dat 41 ondernemingen wel in totaal 149 risico's rapporteren (zie ook tabel 6) die gerelateerd zijn aan hun strategie en business/verdienmodel. Die risico's zijn ook van invloed op de waardering van goodwill en andere activa.

Bij 45 kernpunten (24\%) heeft de onderneming geen kritische grondslag/schatting of risico gerelateerd aan het kernpunt gerapporteerd. Voor de kernpunten die ingaan op de eerstejaarscontrole ligt dit voor de hand aangezien het puur betrekking heeft op de controle en niet op een specifieke jaarrekeningpost of proces van de onderneming. Negen van de $45(20 \%)$ kernpunten

\section{Tabel 3 Aantal gerapporteerde kernpunten, risico's en kritische grondslagen/schattingen}

\begin{tabular}{|l|r|r|r|}
\hline & Kernpunten & Kritische grondslagen/schattingen & Risico's \\
\hline Minimum & 2 & 1 & 2 \\
\hline Mediaan & 4 & 5 & 14 \\
\hline Maximum & 6 & 11 & 28 \\
\hline Gemiddeld & 4,20 & 4,93 & 14,55 \\
\hline Totaal & 185 & 217 & 640 \\
\hline
\end{tabular}

\section{Figuur 4 Best practice Vermelding van de belangrijkste risico's: Delta Lloyd Annual report 2015, p. 20}

In 2015, we identified the following five risks as having the greatest potential impact on Delta Lloyd:

- Inadequate solvency, due to regulatory changes

- Reputational damage, due to declining share price and S\&P downgrade

- Volatile financial markets

- Geopolitical instability

- Increased exposure to cloud computing, cybercrime and data manipulation 
Tabel 4 Vergelijking kernpunten met risicoparagraaf en kritische grondslagen/schattingen

\begin{tabular}{|c|c|c|c|c|c|c|c|}
\hline \multirow[t]{2}{*}{ Onderwerp kernpunt } & \multirow{2}{*}{$\begin{array}{c}\begin{array}{c}\text { Opgenomen als } \\
\text { kernpunt }\end{array} \\
n\end{array}$} & \multicolumn{2}{|c|}{$\begin{array}{l}\text { Tevens opgenomen als kri- } \\
\text { tische grondslag/schatting }\end{array}$} & \multicolumn{2}{|c|}{$\begin{array}{l}\text { Tevens opgenomen in } \\
\text { risicoparagraaf }\end{array}$} & \multicolumn{2}{|c|}{$\begin{array}{l}\text { Niet opgenomen als kritische } \\
\text { grondslag/schatting of risico }\end{array}$} \\
\hline & & $\mathrm{n}$ & $\%$ & $\mathrm{n}$ & $\%$ & $\mathrm{n}$ & $\%$ \\
\hline \multicolumn{8}{|l|}{ Jaarrekening - balansposten } \\
\hline Belastingpositie & 27 & 24 & $89 \%$ & 16 & $59 \%$ & - & $0 \%$ \\
\hline Goodwillwaardering (incl. impairment) & 25 & 23 & $92 \%$ & 4 & $16 \%$ & 2 & $8 \%$ \\
\hline $\begin{array}{l}\text { Overige immateriële- en materiëleactivawaarde- } \\
\text { ring }\end{array}$ & 17 & 13 & $76 \%$ & 7 & $41 \%$ & 3 & $18 \%$ \\
\hline Voorzieningen voor claims en geschillen & 11 & 5 & $45 \%$ & 5 & $45 \%$ & 4 & $36 \%$ \\
\hline Reorganisatievoorziening & 7 & 2 & $29 \%$ & 5 & $71 \%$ & 2 & $29 \%$ \\
\hline Pensioenvoorzieningen & 4 & 4 & $100 \%$ & 4 & $100 \%$ & - & $0 \%$ \\
\hline Overige voorzieningen & 5 & 5 & $100 \%$ & 1 & $20 \%$ & - & $0 \%$ \\
\hline Complexe financiële instrumenten & 6 & 6 & $100 \%$ & 4 & $67 \%$ & - & $0 \%$ \\
\hline Deelnemingen en joint ventures & 4 & 3 & $75 \%$ & 1 & $25 \%$ & 1 & $25 \%$ \\
\hline Overige balansposten & 8 & 6 & $75 \%$ & 3 & $38 \%$ & 1 & $13 \%$ \\
\hline Totaal balansposten & 114 & 91 & $80 \%$ & 50 & $44 \%$ & 13 & $11 \%$ \\
\hline \multicolumn{8}{|l|}{ Jaarrekening - winst-en-verliesrekening } \\
\hline Omzetverantwoording & 20 & 11 & $55 \%$ & 5 & $25 \%$ & 7 & $35 \%$ \\
\hline Totaal winst-en-verliesrekening & 20 & 11 & $55 \%$ & 5 & $25 \%$ & 7 & $35 \%$ \\
\hline \multicolumn{8}{|l|}{ Jaarrekening - ondernemingsspecifiek } \\
\hline Acquisities & 10 & 7 & $70 \%$ & 1 & $10 \%$ & 3 & $30 \%$ \\
\hline Verkoop activiteiten & 6 & 4 & $67 \%$ & - & $0 \%$ & 2 & $33 \%$ \\
\hline Effecten beursgang/overname (delisting) & 3 & - & $0 \%$ & 1 & $33 \%$ & 2 & $67 \%$ \\
\hline Financiering / going concern & 3 & 1 & $33 \%$ & 2 & $67 \%$ & - & $0 \%$ \\
\hline Overig & 4 & 1 & $25 \%$ & - & $0 \%$ & 3 & $75 \%$ \\
\hline Totaal jaarrekening - ondernemingsspecifiek & 26 & 13 & $50 \%$ & 4 & $15 \%$ & 10 & $38 \%$ \\
\hline \multicolumn{8}{|l|}{ Interne beheersing } \\
\hline Betrouwbaarheid en continuïteit IT & 6 & - & $0 \%$ & 6 & $100 \%$ & - & $0 \%$ \\
\hline Overig interne beheersing & 7 & - & $0 \%$ & 2 & $29 \%$ & 5 & $71 \%$ \\
\hline Totaal interne beheersing & 13 & - & $0 \%$ & 8 & $62 \%$ & 5 & $38 \%$ \\
\hline \multicolumn{8}{|l|}{ Overige onderwerpen } \\
\hline Eerstejaarscontrole & 9 & - & $0 \%$ & - & $0 \%$ & 9 & $100 \%$ \\
\hline Overig & 3 & - & $0 \%$ & 3 & $100 \%$ & - & $0 \%$ \\
\hline Totaal overige onderwerpen & 12 & - & $0 \%$ & 3 & $25 \%$ & 9 & $75 \%$ \\
\hline Totaal & 185 & 115 & $62 \%$ & 70 & $38 \%$ & 45 & $24 \%$ \\
\hline
\end{tabular}


waarvoor geen kritische grondslag of risico is gerapporteerd door de onderneming betreffen de eerstejaarscontrole. Andere kernpunten waarvoor relatief vaak geen kritische grondslag/schatting of risico wordt gerapporteerd door de onderneming betreffen omzetverantwoording (7 gevallen, 16\% van de kernpunten zonder kritische grondslag of risico) en interne beheersing (5 gevallen, 11\%). Het is opvallend dat de accountant in desbetreffende gevallen deze punten een belangrijk aandachtspunt heeft gevonden voor de controle terwijl het bestuur van de onderneming hier geen risico of schattingselement in ziet met belangrijke invloed op de jaarrekening.

Uit tabel 5 blijkt dat meer dan de helft (53\%) van de door de ondernemingen gerapporteerde kritische grondslagen en schattingen terugkomt in een door de accountant gerapporteerd kernpunt. Kritische grondslagen en schattingen die, als ze door de onderneming worden gerapporteerd, in veel gevallen ook door de accountant worden gerapporteerd als kernpunt zijn omzetverantwoording (92\%), goodwillwaardering (82\%) en de belastingpositie (73\%). Opvallend is dat pensioenvoorzieningen en overige voorzieningen relatief vaak door de onderneming worden gerapporteerd als kritische grondslag/schatting (beide door 21 ondernemingen gerapporteerd als kritische grondslag/schatting), maar in slechts een beperkt aantal gevallen door de accountant worden gezien als kernpunt van de controle. De pensioenvoorziening wordt slechts bij 19\% van de ondernemingen die het als kritische grondslag/ schatting rapporteren door de accountant ook gezien

\section{Tabel 5 Door de onderneming gerapporteerde kritische grondslagen/schattingen en aantal daarvan dat is opgenomen in een kernpunt}

\begin{tabular}{|c|c|c|c|c|}
\hline \multirow[t]{2}{*}{ Onderwerp kritische grondslag/schatting } & \multicolumn{2}{|c|}{ Opgenomen als kritische grondslag/schatting } & \multicolumn{2}{|c|}{ Tevens opgenomen als kernpunt } \\
\hline & $\mathrm{n}$ & $\%$ & $\mathrm{n}$ & $\%\left(^{*}\right)$ \\
\hline \multicolumn{5}{|l|}{ Balansposten } \\
\hline Belastingpositie & 33 & $15 \%$ & 24 & $73 \%$ \\
\hline Goodwillwaardering (incl. impairment) & 28 & $13 \%$ & 23 & $82 \%$ \\
\hline Overige immateriële- en materiëleactivawaardering & 30 & $14 \%$ & 13 & $43 \%$ \\
\hline Pensioenvoorzieningen & 21 & $10 \%$ & 4 & $19 \%$ \\
\hline Voorzieningen voor claims en geschillen & 10 & $5 \%$ & 5 & $50 \%$ \\
\hline Overige voorzieningen & 21 & $10 \%$ & 7 & $33 \%$ \\
\hline Complexe financiële instrumenten & 12 & $6 \%$ & 6 & $50 \%$ \\
\hline Deelnemingen en joint ventures & 6 & $3 \%$ & 3 & $50 \%$ \\
\hline Overige balansposten & 18 & $8 \%$ & 6 & $33 \%$ \\
\hline Totaal balansposten & 179 & $83 \%$ & 91 & $51 \%$ \\
\hline \multicolumn{5}{|l|}{ Winst-en-verliesrekening } \\
\hline Omzetverantwoording & 12 & $6 \%$ & 11 & $92 \%$ \\
\hline Totaal winst-en-verliesrekening & 12 & $6 \%$ & 11 & $92 \%$ \\
\hline \multicolumn{5}{|l|}{ Overig } \\
\hline Acquisities & 10 & $5 \%$ & 7 & $70 \%$ \\
\hline Verkoop activiteiten & 6 & $3 \%$ & 4 & $67 \%$ \\
\hline Consolidatie & 2 & $1 \%$ & - & $0 \%$ \\
\hline Leases & 2 & $1 \%$ & - & $0 \%$ \\
\hline Overig & 4 & $2 \%$ & 2 & $50 \%$ \\
\hline Totaal overig & 24 & $11 \%$ & 13 & $54 \%$ \\
\hline Totaal & 215 & $100 \%$ & 115 & $53 \%$ \\
\hline
\end{tabular}

${ }^{*}$ ) NB: het betreft hier het percentage gevallen waarbij de kritische grondslag/schatting terugkomt als kernpunt in de controleverklaring. 
als kernpunt van de controle (vier gevallen), overige voorzieningen bij 33\% van de ondernemingen.

De relatie tussen de door de ondernemingen gerapporteerde kritische schattingen en de door de accountant gerapporteerde kernpunten wordt door een aantal accountants expliciet gelegd in de gerapporteerde kernpunten. Een voorbeeld hiervan is de controleverklaring die is opgenomen in de jaarrekening van Arcadis (figuur 5).

Tabel 6 laat zien dat ondernemingen in totaal 640 risico's rapporteren en dat slechts 65 hiervan (10\%) terugkomen in een kernpunt (waarbij ook hier wordt opgemerkt dat in totaal 42 kernpunten zijn gerapporteerd over de waardering van goodwill en andere activa en dat de risico's ten aanzien van externe economische en politieke factoren, consumentenvoorkeuren, concurrentie en overige risico's gerelateerd aan de strategie en het business/verdienmodel hier wel een relatie mee hebben). Risico's ten aanzien van de belastingpositie vinden in $76 \%$ van de gevallen hun weg in een kernpunt van de accountant. Bij de andere veel door de ondernemingen gerapporteerde risico's geldt dat ze slechts zelden door de accountant worden gezien als een kernpunt voor zijn controle. Risico's ten aanzien van de betrouwbaarheid en continuïteit van IT komen nog in zes kernpunten terug, maar andere veel gerapporteerde risico's als financiering en treasury (2), Voldoen aan wet- en regelgeving (1), Continuiteit productie en leve- ring (0) en Talent / human capital (0) komen nauwelijks of helemaal niet terug in de kernpunten van de controleverklaring.

Deze discrepantie tussen de risico's die de ondernemingen het belangrijkste vinden en de kernpunten van de accountant is opvallend. De focus van de kernpunten op de balansposten leidt ertoe dat in de kernpunten de invloed van de risico's op de controle van de accountant minder wordt belicht. Betrouwbaarheid en continuiteit van IT en het voldoen aan wet- en regelgeving worden bijvoorbeeld door veel ondernemingen gezien als belangrijk risico (44 respectievelijk 42 maal gerapporteerd) maar komen nauwelijks terug in de kernpunten. Dat geldt in zijn algemeenheid voor aspecten van de interne beheersing van de gecontroleerde ondernemingen. Dat is opvallend aangezien verwacht mag worden dat juist bij de onderzochte ondernemingen (44 van de grootste beursgenoteerde ondernemingen) het onderzoek van de interne beheersing een belangrijk onderdeel zal zijn van de veelal sterk systeemgerichte controle-aanpak. Een voorbeeld van een controleverklaring waarin de accountant in een kernpunt wel expliciet aandacht geeft aan de interne beheersing bij de gecontroleerde onderneming is de controleverklaring van PostNL (figuur 6).

Ten slotte willen we de aandacht vestigen op een best practice waarin de relatie tussen de door de accoun-

\section{Figuur 5 Best practice Kernpunt ten aanzien van gerapporteerde kritische schattingen: Arcadis Annual report 2015, p. 238 (PwC)}

\section{Key audit matter}

Project revenue recognition and valuation of (un)billed receivables

Project revenue recognition and the valuation of (un)billed receivables are significant to the financial statements based on the quantitative materiality and the degree of management judgement required for revenue recognition and valuation of (un)billed receivables. The complexity and judgments are mainly related to estimation of the cost to complete the projects, expected revenues and the related percentage of completion which the Company applies for recognizing revenues and assessing provisions for projects and loss making contracts. Management has also considered this area to be a key accounting estimate as disclosed in the 'accounting estimates and management judgements' note to the Consolidated financial statements on page 167 .

\section{How our audit addressed the matter}

We tested the key internal controls and IT systems which support the project management and accounting. These included controls in the policies and procedures concerning determination of the percentage of completion, estimates to complete for both revenue and costs and provisions for loss making projects or (un)billed receivables.

Detailed substantive procedures have been performed on individually significant projects as well as high risk projects. This includes challenging the assumptions and estimates applied by management and substantiating transactions with underlying documents like contracts, variation/change orders, correspondence on claims \& disputes, legal opinions and agreements with subcontractors. In addition, we discussed the progress of these projects with the respective project managers and management. Besides aforementioned procedures, specific attention has been given to the completeness and timing of the $€ 14$ million provision recognized for the US environmental remediation project cost overruns as explained on page 97 of the Report by the Executive Board.

We further focused on the Company's disclosures concerning the (un)billed receivables and the related risks such as credit risk, liquidity risk and the ageing of receivables in note 28 to the Consolidated financial statements. 
Tabel 6 Door de onderneming gerapporteerde risico's en aantal daarvan dat is opgenomen in een kernpunt

\begin{tabular}{|c|c|c|c|c|}
\hline \multirow[t]{2}{*}{ Onderwerp risicoparagraaf } & \multicolumn{2}{|c|}{ Opgenomen als risico } & \multicolumn{2}{|c|}{ Tevens opgenomen als kernpunt } \\
\hline & $\mathrm{n}$ & $\%$ & $n$ & $\%$ \\
\hline Externe economische en politieke factoren & 66 & $10 \%$ & - & $0 \%$ \\
\hline Consumentenvoorkeuren & 23 & $4 \%$ & - & $0 \%$ \\
\hline Concurrentie & 20 & $3 \%$ & - & $0 \%$ \\
\hline Overige risico's gerelateerd aan de strategie en het business/verdienmodel & 40 & $6 \%$ & - & $0 \%$ \\
\hline Financiering & 20 & $3 \%$ & 2 & $10 \%$ \\
\hline Andere treasury-gerelateerde risico's & 44 & $7 \%$ & - & $0 \%$ \\
\hline Betrouwbaarheid en continuïteit IT & 44 & $7 \%$ & 6 & $14 \%$ \\
\hline Voldoen aan wet- en regelgeving & 42 & $7 \%$ & 1 & $2 \%$ \\
\hline Continuïteit productie en levering & 39 & $6 \%$ & - & $0 \%$ \\
\hline Talent / human capital & 32 & $5 \%$ & - & $0 \%$ \\
\hline Belastingpositie & 21 & $3 \%$ & 16 & $76 \%$ \\
\hline Gezondheid en veiligheid & 21 & $3 \%$ & - & $0 \%$ \\
\hline Investeringsbeslissingen & 19 & $3 \%$ & - & $0 \%$ \\
\hline Milieu effecten & 17 & $3 \%$ & 1 & $6 \%$ \\
\hline Herstructurering & 16 & $3 \%$ & 2 & $13 \%$ \\
\hline Calamiteiten en verzekering & 16 & $3 \%$ & - & $0 \%$ \\
\hline Financiële verslaggeving & 15 & $2 \%$ & - & $0 \%$ \\
\hline Reputatie & 12 & $2 \%$ & - & $0 \%$ \\
\hline Intellectueel eigendom & 12 & $2 \%$ & - & $0 \%$ \\
\hline Integratie acquisities & 12 & $2 \%$ & - & $0 \%$ \\
\hline Onderzoek en ontwikkeling & 11 & $2 \%$ & 1 & $9 \%$ \\
\hline Overige risico's & 98 & $15 \%$ & 36 & $37 \%$ \\
\hline Totaal & 640 & $100 \%$ & 65 & $10 \%$ \\
\hline
\end{tabular}

\section{Figuur 6 Best practice Accountant besteedt aandacht aan interne beheersing: PostNL Annual report 2015, p. 151 (PwC)}

\section{Key audit matter}

\section{Mitigation of internal control deficiencies}

During 2015 PostNL has spent a considerable amount of time in the strengthening of the IT control framework. Execution of strategic IT projects at the same time reduced the execution power to remediate existing control deficiencies in the area of change management, segregation of duty conflicts and logical access security relating to the financial system and certain underlying operating systems. Furthermore in Germany the Postcon organisation faced capacity constraints as a result of a reorganisation. This resulted in insufficient attention to internal controls in 2015 especially in the area of revenue.

These internal control deficiencies increased the risk of misstatements in financial reporting. Management and Internal Audit performed additional procedures to mitigate the risk.

\section{How our audit addressed the matter}

Our audit procedures included evaluating and testing the additional procedures management put in place to remediate the related risks and the work performed by Internal Audit. In addition we performed additional substantive testing, comprising of, amongst others, assessing whether access rights had not been inappropriately used, validation of transactions processed in areas where segregation of duties conflicts existed, additional testing of revenue transactions, and reconciliation between operational and financial data. 
tant gerapporteerde kernpunten en de door de onderneming gerapporteerde belangrijke schattingen expliciet wordt weergegeven. In de controleverklaring bij de jaarrekening van Unilever wordt expliciet verwezen naar de toelichting bij de jaarrekening en het verslag van de audit committee (best practice 7). Ook wordt melding gemaakt van de communicatie over de kernpunten met de audit committee. In het verslag van de audit committee wordt eveneens ingegaan op de belangrijkste issues ten aanzien van de jaarrekening (welke overeenkomen met de door de accountant gerapporteerde kernpunten) en wordt expliciet melding gemaakt van het feit dat de accountant en de audit committee op één lijn zitten over wat de belangrijkste issues zijn. De achtergrond van deze relatie tussen de rapportages van het audit committee en de accountant is gelegen in de wettelijke bepalingen in het VK dat het audit committee melding maakt van de belangrijkste bespreekpunten met de accountant. Een vergelijkbare actieve dialoog tussen audit commissie is opgenomen in de voorstellen van de Monitoring Commissie Corporate Governance (2016) om ook in Nederland door te voeren.

\section{Samenvatting en conclusies}

Decennialang hebben accountants het oordeel bij de jaarrekening gecommuniceerd via standaardbewoordingen in de controleverklaringen. Stakeholders verwachten echter meer informatie van de accountant. Het beperkte inzicht in de werkzaamheden heeft mede bijgedragen aan de onvrede over het functioneren van accountants. De Werkgroep toekomst accountantsberoep (2014) stelt dat de maatschappij jarenlang te weinig heeft gezien van wat accountants doen en dat niet kan worden verwacht dat de maatschappij haar vertrouwen slechts baseert op de standaardcontroleverklaring. De uitgebreide controleverklaring is een antwoord op deze informatiebehoefte van stakeholders. De kernpunten die door de accountant worden gerapporteerd, kunnen niet los worden gezien van de kritische schattingen die het bestuur moet maken bij het opstellen van de jaarrekening en de belangrijkste risico's die het bestuur ziet. Verwacht mag worden dat deze kritische schattingen en risico's die van invloed zijn op de jaarrekening ook aandacht vragen van de accountant bij zijn controle. In dit artikel is onderzocht in welke mate de kernpunten in de uitgebreide controleverklaring overeenkomen met de genoemde risico's in het bestuursverslag alsmede de kritische grondslagen en schattingen in de toelichting. Wij hebben de bestuursverslagen, jaarrekeningen en controleverklaringen over boekjaar 2015 onderzocht van de 50 ondernemingen die deel uitmaken van de AEX- en

\section{Figuur 7 Best practice Dialoog met audit committee: Unilever Annual report and accounts 2015 (KPMG)}

\begin{tabular}{|c|c|}
\hline Report of the audit committee (p. 60) & Auditor's report (pp. 85 e.v. \\
\hline $\begin{array}{l}\text { Particular attention was paid to the following significant issues in relation to the } \\
\text { financial statements: } \\
\text { - revenue recognition - estimation of discounts, incentives on sales made } \\
\text { during the year, refer to note } 2 \text { on page } 96 \text {; } \\
\text { direct tax provisions and contingencies, refer to note } 6 \text { on pages } 106 \text { to } 108 \text {; } \\
\text { and } \\
\text { indirect tax provisions and contingencies, refer to note } 19 \text { on page } 129 \\
\text { The external auditors have agreed the list of significant issues discussed by the } \\
\text { Audit Committee }\end{array}$ & $\begin{array}{l}\text { Key audit matters: } \\
\text { - } \\
\text { - Indirect tax provisions and contingencies } \\
\text { Direct tax provisions and contingencies } \\
\text { In arriving at our audit opinion above on the Financial Statements the risks of ma- } \\
\text { terial misstatement that had the greatest effect on our audit (key audit matters) } \\
\text { were as set out below and are unchanged from } 2014 \text {. } \\
\text { These are the matters that, in our professional judgement, had the greatest effect } \\
\text { on: the overall audit strategy; the allocation of resources in our audit; and directing } \\
\text { the efforts of the engagement team. We have communicated these matters to the } \\
\text { Audit Committee. Our audit procedures relating to these matters were designed in } \\
\text { the context and solely for the purposes of our audit of the Financial Statements as } \\
\text { a whole, and in forming our opinion thereon, and we do not express discrete opini- } \\
\text { ons on these matters. } \\
\text { (.....) } \\
\text { For each risk noted above refer to related disclosure within the Report of the Audit } \\
\text { Committee (page } 60 \text { ), accounting policies and financial disclosures within the no- } \\
\text { tes to the Consolidated Financial Statements. }\end{array}$ \\
\hline
\end{tabular}


Midkap-index. Uit ons onderzoek blijkt dat de in de uitgebreide controleverklaring genoemde kernpunten vaak overeenkomen met de kritische grondslagen en schattingen zoals verwoord door het bestuur van ondernemingen in de toelichting. De accountant heeft een sterke focus op balansposten als kernpunt waarbij vooral belastingposities en goodwill-impairment vaak voorkomen. Omzetverantwoording komt ook vaak voor als kernpunt. Interne beheersing en controleaspecten worden nauwelijks als kernpunt genoemd. Opvallend is dat pensioenvoorzieningen en overige voorzieningen relatief vaak door de onderneming worden gerapporteerd als kritische grondslag/schatting, maar in slechts een beperkt aantal gevallen door de accountant worden gezien als kernpunt van de controle. De relatie tussen de door de ondernemingen gerapporteerde kritische schattingen en de door de accountant gerapporteerde kernpunten wordt door een aantal accountants expliciet gelegd in de gerapporteerde kernpunten.

In slechts $10 \%$ van de gevallen komt een risico zoals opgenomen in het bestuursverslag terug als kernpunt in de uitgebreide controleverklaring. Hierbij moet wel worden opgemerkt dat veel kernpunten die zijn gerapporteerd over de waardering van goodwill en andere activa een relatie hebben met risico's ten aanzien van externe economische en politieke factoren, consumentenvoorkeuren, concurrentie en overige risico's gerelateerd aan de strategie en het business/verdienmodel van een onderneming. Risico's ten aanzien van de belastingpositie vinden wel vaak hun weg in een kernpunt van de accountant. Bij de andere veel door de ondernemingen gerapporteerde risico's geldt dat ze slechts zelden door de accountant worden gezien als een kernpunt voor zijn controle. De risico's die in het bestuursverslag worden gemeld zijn vaak op een hoger abstractieniveau en verder verwijderd van de vaak technische kernpunten betreffende balansposten in de uitgebreide controleverklaring. Mogelijk komt hier in de toekomst verandering in als gevolg van de toenemende verwachtingen van stakeholders en toenemende verantwoordelijkheid van de accountant ten aanzien van het rapporteren van materiële onjuistheden in het bestuursverslag vanaf 2016.

Zaken als betrouwbaarheid en continuïteit van IT en het voldoen aan wet- en regelgeving worden door veel ondernemingen gezien als risico maar komen nauwelijks terug in de kernpunten. Dat geldt in zijn algemeenheid voor aspecten van de interne beheersing van de gecontroleerde ondernemingen. Dat is opvallend aangezien verwacht mag worden dat juist bij de door ons onderzochte ondernemingen het onderzoek van de interne beheersing een belangrijk onderdeel zal zijn van de veelal sterk systeemgerichte controle-aanpak.

Dr. A.J. Brouwer RA is verbonden aan de Universiteit van

Amsterdam en partner bij PwC.

Prof. dr. P.W.A. Eimers RA is als hoogleraar Auditing ver-

bonden aan de Vrije Universiteit, partner bij PwC en voor-

zitter van het Adviescollege voor Beroepsreglementering

van de Koninklijke NBA.

Prof. dr. H.P.A.J. Langendijk is als hoogleraar Externe ver-

slaggeving verbonden aan Nyenrode Business Universiteit

en de Universiteit van Amsterdam en is tevens werkzaam

als consultant op het gebied van externe verslaggeving.

De auteurs danken Imen Boussaid, Jildit van Brenkelen,

Roel Naafs en Huib ter Voert voor hun assistentie bij het

onderzoek.

\section{Literatuur}

- Accounting Standards Board / Financial Reporting Council (ASB \& FRC) (2011). Cutting Clutter - combating clutter in annual reports. London. Geraadpleegd op https://www.frc. org.uk/Our-Work/Publications/FRC-Board/ Cutting-Clutter-Combating-clutter-in-annualreport.pdf.

- Backhuijs, J.B. \& Roelofsen, E.M. (2014). Kritische grondslagen en schattingsonzekerheden in de jaarrekening. Maandblad voor Accountancy en Bedrijfseconomie, 88(12): 479-491.

- Bos, A. de \& Strating, H. (2014). Nieuwe controleverklaring bezig aan snelle opmars. Maandblad voor Accountancy en Bedrijfseco- nomie, 88(11): 430-439.

- Brouwer, A.J., Eimers, P.W.A., Groot, J. de, \& Groot, F. de (2014). Klare Taal - Benchmark controleverklaring 'nieuwe stij]' onder Nederlandse beursfondsen. PwC. Geraadpleegd op https://www.pwc.nl/nl/assets/documents/ pwc-klare-taal.pdf.

- Camfferman, C., \& Eeftink, E. (2006). Veronderstellingen en schattingen bij het opstellen van de jaarrekening. In: R.G. Bosman, C. Camfferman \& R.G.A. Vergoossen (redactie). Het jaar 2005 verslagen, (67-90). Deventer: Kluwer.

- Christensen, B., Glover, S., Steven, S., \& Wolfe, C. (2014). Do critical audit matter para- graphs in the audit report change nonprofessional investors' decision to invest? Auditing: A Journal of Practice \& Theory, 33(4): 71-93.

- Czerney, K., Schmidt, J.J., \& Thompson, A. (2014). Does auditor explanatory language in unqualified audit reports indicate increased financial misstatement risk? The Accounting Review, 89(6): 2115-2149.

- Daelen, M.M.A. van (2013). Een format voor de openbaarmaking van risico-informatie. Maandblad voor Accountancy en Bedriffseconomie, 87(7/8): 316-324.

- Daelen, M.M.A. van, \& Groot, J.I. de (2014). Risicoverslaggeving in het directieverslag in beweging. Maandblad voor Accountancy en 
Bedriffseconomie, 88(12): 543-555.

- Eimers, P.W.A., \& Groot, F.J.L. de (2015), De controleverklaring bij de jaarrekening: ínformatiever en relevant', Handboek Accountancy, Suppl. 45 (december 2015).

- Eumedion (2012). Eumedion Spearheads Letter 2013. 9 oktober 2012. Den Haag. Geraadpleegd op http://wwww. eumedion.n//en/public/ knowledgenetworkspeerheadsletter/2013 spearheads_letter.pdf.

- Eumedion (2013). Verzoek om een meer ondernemingsspecifieke controleverklaring bij de jaarrekening van Nederlandse beursvennootschappen. 7 oktober 2013. Den Haag. Geraadpleegd op http://www.eumedion.n//nl/ public/kennisbank/speerpuntenbrief/brief_ aan_accountantskantoren.pdf.

- Eumedion (2015). Evaluatie van het AvA-seizoen 2015. Den Haag. Geraadpleegd op http://www.eumedion.n//n//public/kennisbank/ ava-evaluaties/2015-ava-evaluatie.pdf.

- Europese Unie (EU) (2014), Verordening (EU) nr. 537/2014 van het Europees Parlement en de Raad - betreffende specifieke eisen voor de wettelijke controles van financiële overzichten van de organisaties van openbaar belang en tot intrekking van Besluit 2005/909/EG van de Commissie. Brussel. Geraadpleegd op http://eur-lex.europa.eu/ legal-content/NL/ TXT/?uri=CELEX\%3A32014R0537.

- Financial Reporting Council (FRC) (2009). Louder than Words: Principles and actions for making corporate reports less complex and more relevant. FRC: Londen. Geraadpleegd op http://frc.org.uk/Our-Work/Publications/FRCBoard/Louder-than-words-File.pdf.

- Financial Reporting Council (FRC) (2016). Extended auditor's reports. A further review of experience. FRC: Londen. Geraadpleegd op https://wwww.frc.org.uk/Our-WorkPublications/Audit-and-Assurance-Team/Report-onthe-Second-Year-Experience-of-Extended-A. pdf.

- Gold, A., Gronewold, U., \& Pott, C. (2012). The ISA 700 auditor's report and the audit expectation gap - Do explanations matter? International Journal of Auditing, 16(3): 286-307.

- Gray, G.L., Turner, J.L., Coram, P.J., \& Mock, T.J. (2011). Perceptions and misperceptions regarding the unqualified auditor's report by financial statement preparers, users, and auditors. Accounting Horizons, 25(4): 659-684.

- Hoogervorst, H. (2012). Speech by Hans Hoogervorst, Mexico March 2012. Geraadpleegd op http://wwww.ifrs.org/News/Announcements-and-Speeches/Pages/HansHoogervorst-Mexico-March-2012.aspX.

- International Auditing and Assurance Standards Board (2015). ISA 701 Communicating key audit matters in the independent auditor's report. New York

- Litjens, H.J.R., \& Vergoossen, R.G.A. (2012). De controleverklaring en de verwachtingskloof in het midden- en kleinbedrijf. Maandblad voor Accountancy en Bedrijfseconomie, 86(3): 58-73.

- Mertens, G.M.H. \& Bili, I.H.C. (2008). Inzicht in onzekerheid. Onderzoek naar de risicoparagrafen in de jaarverslagen 2007 van beursfondsen. Heerlen.

- Monitoring Commissie Corporate Governance Code (2008). De Nederlandse corporate governance code - Beginselen van deugdelijk ondernemingsbestuur en best practice bepalingen. Den Haag. Geraadpleegd op http:// uww. commissiecorporategovernance.n// download/?id=609.

- Monitoring Commissie Corporate Governance Code (2016). De Nederlandse corporate governance code - Voorstel voor herziening Een uitnodiging voor commentaar. Den Haag. Geraadpleegd op http://www.estibbe.com/ corpgov/documenten/Consultatiedocument\%20Code.pdf.

- Nederlandse Beroepsorganisatie van Accountants (NBA) (2013). Accountant, wat heb je te vertellen? De accountant in de aandeelhoudersvergadering (AVA) - Onderzoek naar de praktijk in 2013. Amsterdam, Geraadpleegd op https://www.nba.n//Documents/Onderzoeksrapporten/NBA-Studierapport-Accountant-in-AVA-nov13.pdf.

- Nederlandse Beroepsorganisatie van Accountants (NBA) (2015). Inzicht in de uitgebreide controleverklaring - Toepassing van Standaard 702N over boekjaar 2014. Amsterdam. Geraadpleegd op https://www.nba.n//Documents/Nieuws/Pdfs/NBA_Rapport_Inzicht_ Uitgebreide_Controleverklaring.pdf.

- Public Company Accounting Oversight Board (PCAOB) (2015). Fact sheet: Auditor's Reporting
Model Reproposal. Geraadpleegd op https:// pcaobus.org/News/Releases/Pages/Fact-SheetReproposal-Auditors-Report-051116.aspx.

- PwC (2015). Arjan Brouwer in gesprek met Rients Abma. Spotlight - Vaktechnisch bulletin van PwC Accountants, 22(2): 7-11. Geraadpleegd op https://www.pwc.n//n//spotlight/assets/documents/2015/ pwc-spotlight-2015-2-brouwer-in-gesprekmet-rients-abma.pdf.

— PwC (2016). In gesprek met Arnold Schilder. Spotlight - Vaktechnisch bulletin van PWC Accountants, 23(2): 7-11.

- Ridder, W.P. de, \& Steggink, J. (2009). Verantwoording over risicobeheersing - Wat willen aandeelhouders, banken en ondernemingsraden weten? Maandblad voor Accountancy en Bedriffseconomie, 83(7/8): 247-253.

- Turner, J.L, Mock, T.J., Coram, P.J., \& Gray, G.L. (2010). Improving transparency and relevance of auditor communications with financial statement users. Current /ssues in Auditing, 4(1):A1-A8.

- Vereniging van Effectenbezitters (NEB) (2013). Aandeelhoudersvergaderingseizoen 2013 en de verwachte bijdrage van de accountant (accountantsbrief). 3 januari 2013. Den Haag.

- Vereniging van Effectenbezitters (VEB) (2015). Aandeelhoudersvergaderingseizoen 2015 en de verwachte bijdrage van de accountant (accountantsbrief). 29 januari 2015. Den Haag.

- Vereniging van Effectenbezitters (NEB) (2016). Aandeelhoudersvergaderingseizoen 2016 en de verwachte bijdrage van de accountant (accountantsbrief). 25 januari 2016. Den Haag.

- Werkgroep toekomst accountantsberoep (Brouwer, A.J., Clement, D., Van Es, N., Jongeneel, T., Lauret, M-P., Saasen, P-P., \& Segers, C.) (2014). In het publiek belang Maatregelen ter verbetering van de kwaliteit en onathankelijkheid van de accountantscontrole. Werkgroep Toekomst Accountantsberoep, Amsterdam. Geraadpleegd op https:// www.nba.n/Documents/Nieuws/2014/pdfs/ In\%20het\%20publiek\%20belang\%20rapport\%20WG\%20Toekomst\%20Acc\%20 25sep14.pdf.

- Wieringa, P.A. (2015) Wat accountants moeten communiceren en uitstralen. Maandblad voor Accountancy en Bedrifseconomie, 89(3): 112-116. 


\section{Bijlage 1 Lijst van onderzochte ondernemingen}

\begin{tabular}{|r|l|}
\hline \multicolumn{1}{|l|}{ AEX } & \\
\hline 1 & Aalberts \\
\hline 2 & ABN AMRO \\
\hline 3 & AEGON \\
\hline 4 & Ahold \\
\hline 5 & Akzo Nobel \\
\hline 6 & Altice \\
\hline 7 & Arcelor Mittal \\
\hline 8 & ASM Litho \\
\hline 9 & Boskalis \\
\hline 10 & DSM \\
\hline 11 & Gemalto \\
\hline 12 & Heineken \\
\hline 13 & ING \\
\hline
\end{tabular}

\begin{tabular}{|r|l|}
\hline \multicolumn{1}{|l|}{ AEX } & \\
\hline 14 & KPN \\
\hline 15 & NN Group \\
\hline 16 & Philips \\
\hline 17 & Randstad \\
\hline 18 & RD Shell-A \\
\hline 19 & RELX Group \\
\hline 20 & SBM Offshore \\
\hline 21 & TNT Express \\
\hline 22 & Unibail \\
\hline 23 & Unilever \\
\hline 24 & Vopak \\
\hline 25 & Wolters Kluwer \\
\hline & \\
\hline
\end{tabular}

\begin{tabular}{|c|l|}
\hline Midkap & \\
\hline 26 & Air France-KLM \\
\hline 27 & Aperam \\
\hline 28 & Arcadis \\
\hline 29 & ASM Int. \\
\hline 30 & BAM Groep \\
\hline 31 & BE Semiconduc- \\
\hline 32 & tors. \\
\hline 33 & Corbion \\
\hline 34 & Eurocom- \\
\hline 35 & Floyd \\
\hline 36 & Fugro \\
\hline 37 & Galápagos \\
\hline
\end{tabular}

\begin{tabular}{|c|l|}
\hline Midkap & \\
\hline 38 & GrandVision \\
\hline 39 & IMCD \\
\hline 40 & Intertrust \\
\hline 41 & NSI \\
\hline 42 & OCI \\
\hline 43 & PostNL \\
\hline 44 & Sligro \\
\hline 45 & TKH Group \\
\hline 46 & TomTom \\
\hline 47 & USG People \\
\hline 48 & VastNed Retail \\
\hline 49 & WDP(be) \\
\hline 50 & Wereldhave \\
\hline
\end{tabular}

